\section{Costs of cardiovascular disease}

Re: Long-term trends in use of and expenditures for cardiovascular medications in Canada, July 7

The findings of Jackevicius et al do not surprise me. It would be interesting to know, along with the disparity of spending among the provinces, their respective prevalence of cardiovascular disease. Isn't it time for our society and our medical schools to wake up and take a hard look at non-medicinal preventive measures? That would include having knowledgeable researchers and physician-teachers who understand nutrition (none in my day) and other lifestyle issues. This may mean physicians' organizations getting out of the closet in order to influence public policy, education and pediatric care. In the end that may reduce expenditures.

\section{Dr. David Rosen \\ Mississauga ON}

Competing interests: None declared.

For the full letter, go to: www.cmaj.ca/cgi/eletters/181/1-2/E19\#140835

DOI:10.1503/cmaj.109-2002

\section{Cord blood banking}

A news feature and editorial in the June 23 issue argue for a national program for cord blood banking in Canada. The executive director of OneMatch Stem Cell and Marrow Network is quoted as saying: "This is something that is otherwise medical waste that can truly save lives." One should be aware that the collection process entails early clamping of the umbilical cord, in order to recover an adequate volume of blood, a practice that may not be in the best interests of the newborn donor. Delaying for a sufficient time to allow the physiologic placental transfusion has been shown to reduce the incidence of anemia in full-term infants and to improve their iron status in infancy. While not denying the potential benefits of cord blood banking, the product in the bank should not be regarded as "medical waste" and, in consenting to its collection, parents should be fully informed of the costs.

\section{John A. Smyth LRCPSI}

Department of Pediatrics, University of

British Columbia, Vancouver BC

Eileen K. Hutton PhD

Department of Obstetrics and Gynecology, McMaster University, Hamilton ON

Competing interests: None declared.

For the full letter, go to: www.cmaj.ca/cgi/eletters/180/13/1279\#142234

DOI:10.1503/cmaj.109-2007

\section{Doctors and climate change}

Re: Physicians' contribution to climate change, Salon, May 26

JunkScience.com's "Ultimate Global Warming Challenge' is offering US\$500 000 for the first person to prove scientifically the "Humans cause global warming hypothesis." The prize goes up at regular intervals and will reach $\$ 1$ million in the near future. So, if Dr. Mehta has his evidence, let him claim his prize and stop flagellating the "lowly physician."

\section{Dr. Andris Lielmanis}

Family practice [not an oil executive]

Competing interests: None declared.

For the full letter go to: www.cmaj.ca/cgi/eletters/180/11/1176\#136867

DOI:10.1503/cmaj.109-2008

\section{Hippocrates vs. misanthropism}

I agree with Dr. Mehta (Salon May 26) that physicians have a role in raising consciousness to reverse the effects that human arrogance/ignorance has had on the Earth. I feel, however, that he is part of a trend within the Green movement that goes to a misanthropic extreme. Within his argument, language and ideas are used that likens the human race to, for example, a rabbit population that needs to be culled. Insidiously related to this is the notion that, like rabbits, humans are totally subject to instinctual drives. If we, as physicians, perpetuate this cynical view of humans as automatons, we will continue to hand over fertilityreducing technology exclusively and abandon the biopsychosocio-spiritual model that views human beings as more than matter.

\section{Jonathan S. Ponesse \\ Assistant professor of pediatrics University of Ottawa}

Competing interests: None declared.

For the full letter, go to: www.cmaj.ca/cgi/eletters/180/11/1176\#137192

DOI:10.1503/cmaj.109-2000

\section{Weight control trial}

Re: Determining optimal approaches for weight maintenance: a randomized controlled trial, published May 12

The subjects chosen for this study were female volunteers with Class I obesity (average BMI $31 \mathrm{~kg} / \mathrm{m} 2$ ) with reported pretrial weight loss of 9 per cent of their body weight. These patients rarely require referral to obesity management programs and may comprise a minority of patients managed in the primary care setting. The remarkable finding from this study is that not only did patients sustain their initial weight loss, but they continued to lose weight over the 2 years of follow-up. Were average caloric intakes assessed in these patients? We suspect that this trial represents the unique accomplishment of a highly successful, motivational team with a highly selected and motivated group of patients. The authors are to be congratulated on their findings, however we are not con- 